\title{
Predatory and Fake Scientific Journals/Publishers - A Global Outbreak with Rising Trend: A Review
}

\author{
Lukić Tin ${ }^{A^{*}}$, Blešić IvanaA, Basarin BiljanaA, Ivanović Bibić LjubicaA, Milošević Dragan ${ }^{\mathrm{A}}$, Sakulski Dušan ${ }^{\mathrm{B}}$ \\ Received: June 15, 2014 | Revised: July 29, 2014 | Accepted: August 28, 2014
}

\begin{abstract}
In recent times some publishers are intensively exploiting the model of open access publishing. During the last several years, studies have shown that there was a substantial increase in the number of fake publishers and hijacked journals. These cyber criminals make money by stealing the identities of legitimate journals and collecting the article processing charges on the papers that are submitted. This is all accomplished by a well developed framework that includes web development steps, intensive e-mail marketing and victim selections. This review article strives to recommend that the Beall's list of predatory publishers and journals should be consulted every time when an author plans to submit scientific work to some of the journals that are indexed by Thomson Reuters/Institute for Scientific Information-ISI and covered by the Journal Citation Report. Also, the authors are advised to be "up to date" with new information regarding this controversial topic by informing themselves through various websites and specialized scientific portals. The review paper itself strives to summarize the most recent investigations on predatory and spurious journals/publishers which affect the entire scientific community, thus representing an outbreak with rising trend not only on national and regional level, but on global level as well.
\end{abstract}

Key words: predatory, journals, publishers, hijacking, cyber criminals, scientific publishing, Beall's list

\section{Introduction}

In the academic sphere of publishing some publishers are exploiting the model of open access publishing. This means that these publishers may accept the manuscripts that are flawed in terms of scientific and/ or scholarly quality or charge substantial fees to authors without providing essential editorial and publishing services. These publishers are known as predatory open access journal publishers. This provocative term "predatory open access" was conceived by Jeffrey Beall, Associate Professor and Scholarly Initiatives Li- brarian, Auraria Library, University of Colorado Denver, USA (Beall, 2012; Rahman, et al., 2014).

Journal hijacking has become an important issue in the academic world. During the last several years, studies have shown that there was a substantial increase in the number of fake publishers and hijacked journals (e.g. "Wulfenia Journal", "Archives des Sciences", "Jökull Journal", "Bothalia", "Pensée Journal", "Sylwan", "Ciencia e tecnica vitivinicola", "CADMO" etc). The academic community has read with great interest the paper published in the journal "Nature" in which

A University of Novi Sad, Faculty of Science, Department of Geography, Tourism and Hotel Management, Trg Dositeja Obradovića 3, 21000 Novi Sad, Serbia

B University of the Free State, Disaster Management Training and Education Centre (DiMTEC), 205 Nelson Mandela Drive, Park West, Bloemfontein, South Africa

* Corresponding author: Lukić Tin, e-mail: tin.lukic@dgt.uns.ac.rs 
Declan Butler reported two sham journals that were scamming authors (Butler, 2013). According to Butler (2013), two print-only journals that do not offer electronic versions (only hard copy version) were hijacked by cyber criminals. The hijackers set up fake websites and took money from authors who were attempting to publish their original research work in one of the journals indexed by Science Citation Index Expanded (SCIE), a Thomson Reuters metric product that compiles impact factors (IF) for covered journals (Jalalian, Mahboobi, 2014).

Hijackers make money by stealing the identities of legitimate journals and collecting the article processing charges on the papers that are submitted. According to the recent research of Jalalian and Mahboobi (2014), the cybercriminals have cheated thousands of professors and Ph.D. scholars (mostly from developing countries) and those who were in the urgent need of publishing their articles in journals that are covered by the Journal Citation Report (a Thomson Reuters product). The fake scientific journals targeted their potential victims using smart ideas both in web development steps, e-mail marketing and victim selections, thus making themselves hard to distinguish from the authentic journals. Usually the target groups of the cyber criminals are journals with not so high impact factor value (IF), because it would be difficult for the hijackers to convince the authors that a high impact factor journal invited them to publish their research work, with peer review process done within just a couple of weeks. Unfortunately, claiming a low impact factor $(>0.0)$ on the fake website is good enough for authors who are trying to get their work published in a Thomson Reuters indexed journal in the shortest possible time (Jalalian, Mahboobi, 2013; 2014).

Also, respectable journal "Science" published the controversial article written by John Bohannon, a biologist and science journalist based at Harvard University. Bohannon's paper addresses the research in which author himself applied to different open-access publishers by submitting a fake scientific article to a large number of fee-charging open-access journals, revealing that less than $40 \%$ were living up to their promise of rigorously peer-reviewing what is published (Bohannon, 2013). The news about this research quickly echoed through the entire scientific community making the spotlight and posing some important questions regarding the ethics in scientific publishing and quality of academic research in general.

This review paper strives to summarize the most recent investigation on this important topic which affects the entire scientific community, thus representing a global outbreak with rising trend.

\section{Hijacked Scientific Journals - a tool for cyber criminals}

Stories about fake websites that deceive people into paying for "goods that are never delivered" have been mentioned for many years. Today, a quality research work is only considered as such if it is published in journals that have an impact factor (IF), thus making the academic publishers shifting from a traditional business model to an open-access model (Jalalian, Mahboobi, 2014). All this have made it profitable enough for scammers to add a new line in their business: "Real Money from Fake Journals" (e.g. Beall, 2012; Butler, 2013; Jalalian, Mahboobi, 2014).

As presented in the study of Jalalian and Mahboobi (2014), during the last several years, observations pointed out that cyber criminals have started to imitate the names of respectable scientific journals that publish only printed versions of articles. Such spurious journals involved not only some relatively young journals, but also journals with long tradition in publishing such as "Wulfenia Journal" and "Archives des Sciences" respectively (Figure 1).

Investigating these kinds of fake journals, Jalalian and Mahboobi (2014) found evidence of the hijacking of "Jökull Journal" from Iceland, a South Africanbased journal entitled "Bothalia" and an old French journal "Pensée Journal", all of which have their impact factor compiled by Journal Citation Report (JCR) (IF varied from 0.017 to 1.067). Recent investigations noticed one more active spurious journal with hijacked website (http://scholarlyoa.com/2014/05/02/ red-alert-polish-scholarly-journal-is-hijacked/), "Sylwan", one of the oldest scientific journals in the world covering forestry topics, established in 1820 as the semi-official representative of the Royal Forestry Corps in Poland (IF 0.295). Since 1966 it has been published by the Polish Forestry Society (http://sylwan. ibles.waw.pl/pls/apex/f?p=SYLWAN:profil:o::.:::/) (Figure 2). The hijacked version of the website purports to be the "English Edition" of the journal. Also, cyber criminals edited the Wikipedia article to add the counterfeit web address and distributed a call for papers to the academic public via e-mail, spamming for article submissions. Unfortunately, the indication is that this number of active spurious journals will likely continue to grow and expand on global level (Jalalian, Mahboobi, 2014).

The most incredible thing is that cyber criminals are acting in a very fast way. Only during month of June and July 2014 the report from Dr. Mehrdad Jalalian, who is actively involved in research of publication ethics in academic journalism, indicated big hijack of at least seven scientific journals such as: "Natura" from Netherlands, "Doriana" from Italy, 


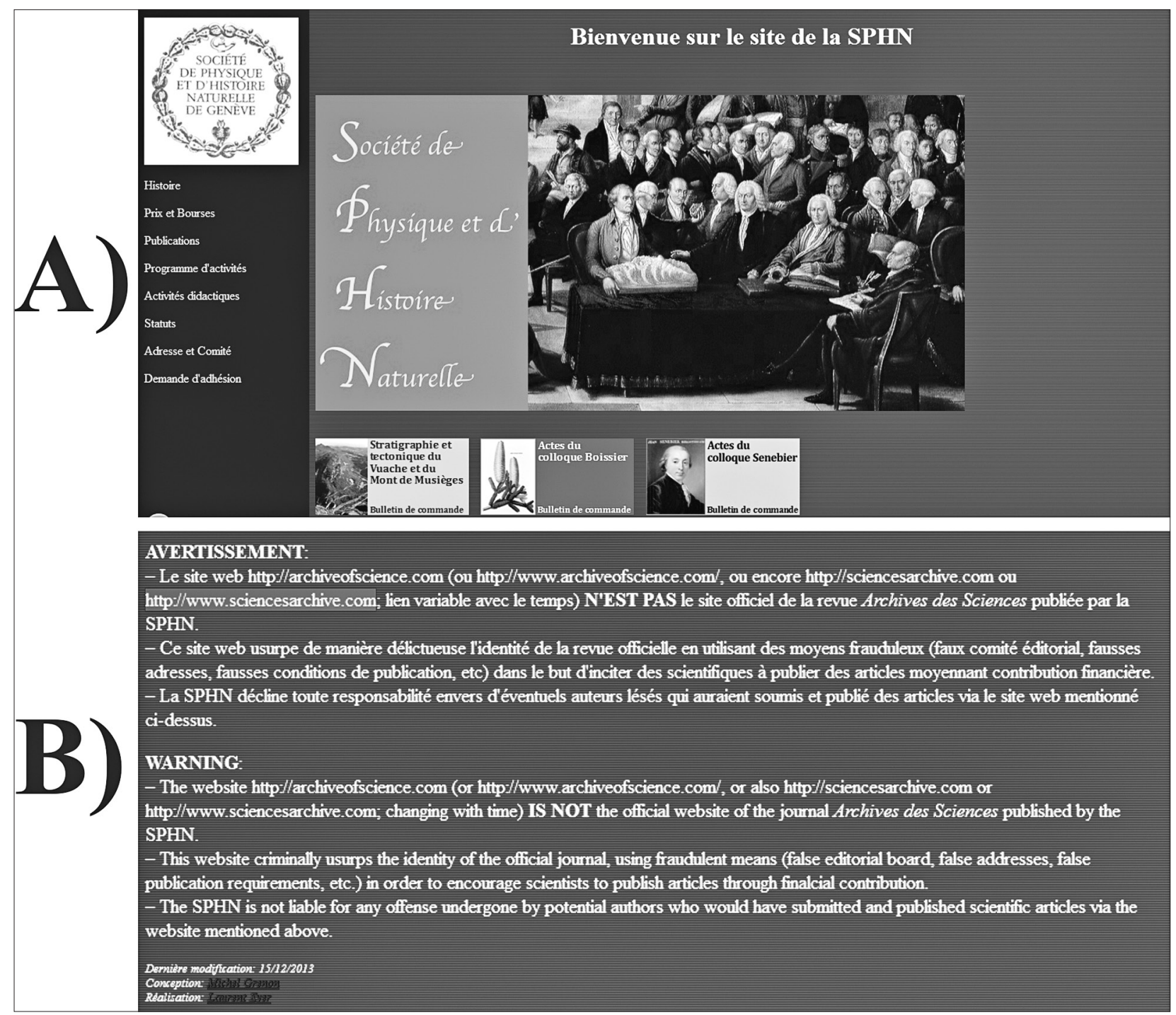

Figure 1. Official website of the Archives des Sciences scientific journal (A) and warning message about journal hijacking with posted internet sites addresses of the fake journal (B)

Source: http://www.unige.ch/sphn/

"Cahiers Des Sciences Naturelles" from Switzerland, and "Mexican Journal of international studies" from Mexico. The hijackers cheated the Thomson Reuters by providing a web link to their fake website. Also, the "Journal of Balkan Tribological Association" from Bulgaria, "Ciencia e tecnica vitivinicola" from Portugal and "CADMO" (Giornale italiano di Pedagogia sperimentale/ Italian Journal of Experimental Pedagogy) from Italy have been hijacked by the cyber criminals as well (http://www.mehrdadjalalian.com/). Spatial distribution of some recently hijacked scientific journals is presented in Figure 3.

Paying for real, open-access publications is a reasonable thing to do, but the money should go to reputable, not spurious journals. The extent to which thousands of authors have incurred strong negative impacts as the result of having been duped into publishing in spurious journals is sad, both for those authors and the scientific community at large. Fake web- sites of hijacked journals can be created by almost anyone who has even minimal knowledge of how to design a website by using an open-source Content Management Systems (CMSs). According to the Jalalian and Mahboobi (2014), cyber criminals are definitely familiar with author's behaviors, and they know that many of authors are in urgent need of publishing a couple of "ISI papers" (i.e. articles published in journals that are indexed by Thomson Reuters/Institute for Scientific Information-ISI) within a limited period of time. In the Republic of Serbia, a journal published by the Serbian Biological Society is currently under investigation by the Centre for Evaluation in Education and Science (CEON/CEES), which runs the Serbian National Citation Index in cooperation with the National Library of Serbia. The investigation follows a revelation by Scholarly Open Access blog that the journal, "Archives of Biological Sciences", accepted a scientific paper within the 24 hours with no peer re- 


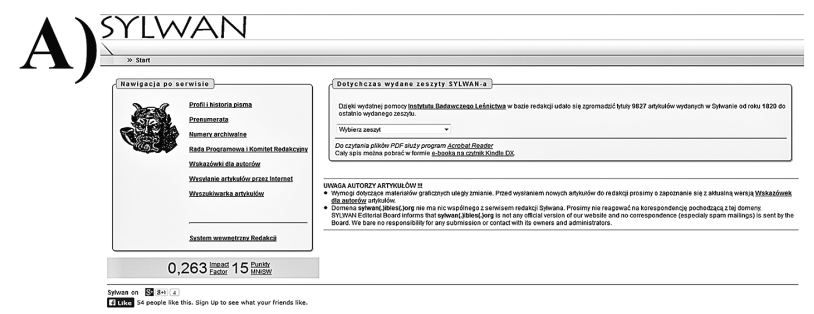

B)

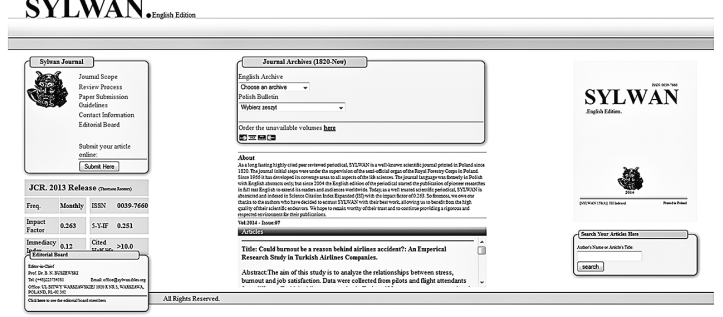

\section{C)}

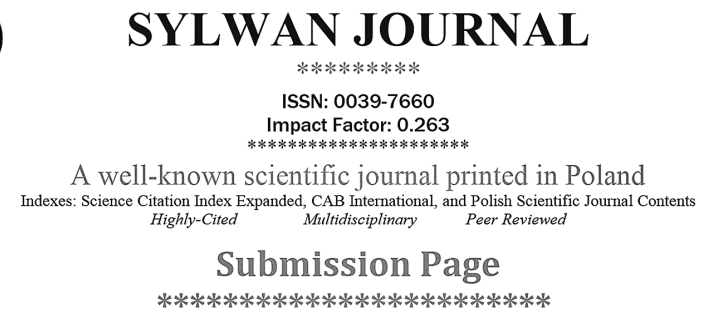

http://sylwan.ibles.org/submit.html

view and demanded 1,785 Euros to publish it. Due to this affair, CEON/CEES have also started a bibliometric analysis to address the accusations, before deciding on the course of action (http://www.scilogs.com/ balkan_science_beat/serbian-journal-archives-of-biological-sciences-under-investigation-following-ac-
Figure 2. Legitimate Sylwan journal website (A) (http:// sylwan.ibles.waw.pl/pls/apex/f?p=105:1:0), hijacked journal website (B) (http://sylwan.ibles.org/) and a screenshot of the spam e-mail being distributed to the academic community (C) (http://scholarlyoa.com/2014/05/02/redalert-polish-scholarly-journal-is-hijacked/). (To trick people, the counterfeit website contains much correct information lifted from the authentic journal website)

cusation-of-predatory-practice/). Also, during 2014 in the Autonomous province of Kosovo and Metohija (Southern Serbia), University of Priština's Rector has been pressured to resign after it was revealed he published articles in predatory journals (according to Beall's list) in order to meet the requirements for promotion to a full professor. Three articles were published in volume 4, issue 3 (2013) of the "International Journal of Engineering and Management Sciences", a journal published by the Lucknow, India-based publisher Society for Science and Nature (http://scholarlyoa.com/2014/01/24/university-of-pristina-rectorunder-fire-for-publishing-in-predatory-journals/). In addition, an article co-authored by the above mentioned Rector was published in the scandal-plagued Romanian scientific journal "Metalurgia International". The target of a sting operation which was performed by the professors from the Faculty of Organizational Sciences- University of Belgrade (Serbia) during 2013 has led to the removal of the "Metalurgia International" impact factor (IF) and predatory journal disappearance from the internet (http:// scholarlyoa.com/2014/o1/24/university-of-pristina-

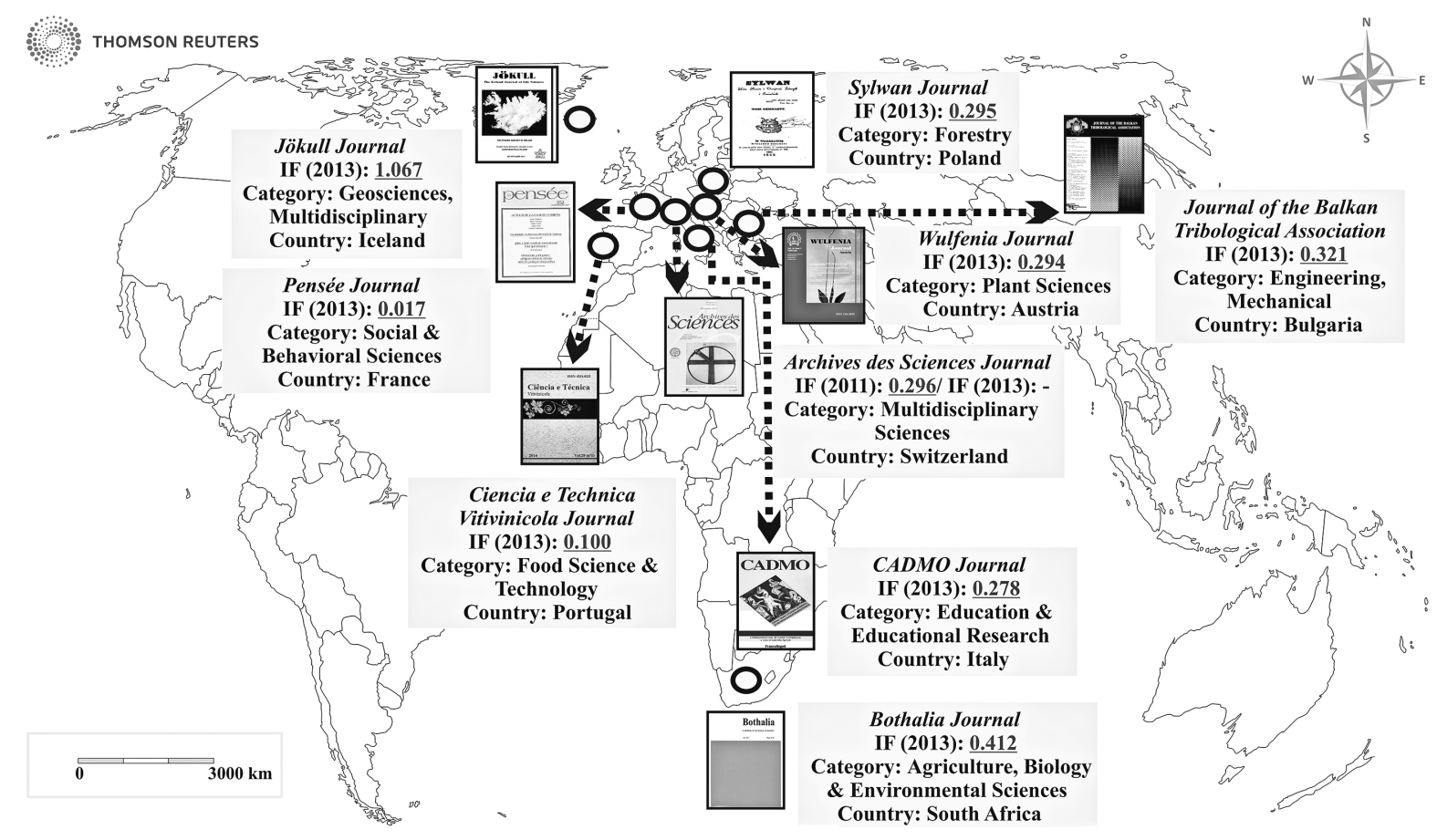

Figure 3. Spatial distribution of some of the recently hijacked scientific journals Source: authors' work according to http://www.mehrdadjalalian.com/ and http://kobson.nb.rs/kobson.82.html 
rector-under-fire-for-publishing-in-predatory-journals/). Scientific community in Serbia is somewhat unprotected to this negative trend and insufficiently informed by the Ministry of Education, Science and Technological Development, KoBSON Portal and COBISS platform. These services provide very general information about predatory journals with highlights on the Jeffrey Beall's classification of predatory publishers and most likely predatory journals (http://kobson.nb.rs/kobson.82.html). There is an appeal to the researchers to check the International Standard Serial Number (ISSN) of the journal, not bearing in mind that some spurious journals have copied the original ISSN number to their site, making them hard to distinguish from the authentic journals. In the section of the KoBSON electronic journal database there should be a warning against some of the highly suspicious scientific journals which have been hijacked by the cyber criminals over the last several years in order to prevent possible frauds.

\section{Guidelines for identifing the predatory scientific journals}

In the past, a journal title that was unfamiliar to a researcher would be an automatic red-flag for journal quality. As the number of journals increases exponentially (Larsen, von Ins, 2010), scholars and academic researchers have turned to a wide variety of tools to help separate quality publications from the rest. Journal metrics like the impact factor (IF) (Garfield, 2006) and a journal's h-index have been used (and misused) extensively. In recent years, librarian Jeffery Beall has put together a list of the worst journals of all, so-called "predatory journals". Also, he assembled a list of the "predatory publishers" by applying the specially designated criteria. The list of questionable, scholarly openaccess journals is presented in Table 1 (see appendix) (http://scholarlyoa.com/individual-journals/). The list of potential, possible, or probable predatory scholarly open-access publishers is available on: $h t t p: / / s c h o l a r l y-$ oa.com/publishers/.

Jeffrey Beall regularly updates this list. He sets forth criteria for categorizing predatory publications and lists publishers and independent journals that meet those criteria (http://scholarlyoa.com/2012/11/30/criteria-for-determining-predatory-open-access-publishers-2nd-edition/). According to "Nature" Beall's list and website are "widely read by librarians, researchers and open-access advocates, many of whom applaud his efforts to reveal shady publishing practices" (Butler, 2013). Beall has instituted a four person review body to which publishers can appeal (http://scholarlyoa.com/appeals) in order to be removed from the list in case they feel their inclusion is unjustified.
Some of the criticisms that are associated with predatory open access publishing also include:

1. Accepting articles quickly without peer review or quality control, including hoax and nonsensical papers (Gilbert, 2009; Basken, 2009).

2. Aggressively campaigning for academics to submit articles or serve on editorial boards (Butler, 2013).

3. Listing academics as members of editorial boards without their permission (Beall, 2012), and not allowing academics to resign from editorial boards (Kolata, 2013).

4. Appointing fake academics to editorial boards. In some cases the editor and/or review board members do not possess academic expertise to reasonably qualify them to be publication gatekeepers in the journal's field (Rahman et al., 2014).

5. Rapid review and production times (e.g. around 1015 days between submitting a draft to final publication) raise questions about the thoroughness of the review process and the quality of the publication process (Rahman et al., 2014).

6. Mimicking the name or website style of more established journals (Kolata, 2013).

7. Majority of the journals is not listed in standard periodical directories and is not widely cataloged in library databases (Rahman et al., 2014).

8. There is no indication of the journal's digital preservation policies (Rahman et al., 2014).

9. Some of the journals combine two or more fields that are not normally treated together. For example: "International Journal of Philosophy and Social Sciences [IJPSS]", "Global Journal of Pharmaceutical Sciences and Education [GJPSE]", "Journal of Applied Mathematics and Fluid Mechanics [JAMFM]" etc (Rahman, et al., 2014).

10. The journal/publisher claims to be indexed in services that however are not abstracting and/or indexing services. For example: Scribd, DocStoc, Cabell's, Ulrich's (Rahman et al., 2014).

11. Predatory open access publishers often produce a large number of journals. For example: a) Academic and Scientific Publishing: 355 titles b) Scientific Research Publishing: 351 titles, c) International Scholars Journals: 343 titles and d) BioInfo Publications: 292 titles (Rahman et al., 2014).

12. Sometimes the publishers lift the aims and scope of an established journal, for example: "The Global Journal of Academic Librarianship [GJAL]" has been lifted from the Journal of Academic Librarianship (http: //www.journals.elsevier.com/the-journalof-academic-librarianship/). The aims and scope of "The International Journal of Librarianship and Administration" has been lifted from the "Journals of Librarianship and information Science" (http://www. sagepub.com/journals/Journal201675/title). 
13. Some predatory open access publishers intentionally assigned the word "International" or "Global" in front of well-established and popular journals, for example: "International Journal of Applied Physics [IJAP]", whereas the "Journal of Applied Physics" is published by IEEE (Rahman, et al., 2014).

\section{Conclusion and future preventive strategies}

Fake publishers and impact factors (IF) indicate an urgent need to evaluate the methods that are currently used to assess academic research. Doing a thorough retrospective assessment of journals and publishers is definitely an urgent need in today's academic world. Also, if author is considering publishing a research work in a scientific journal that is characterized as "reputable journal" there are few crucial things to consider following the pre-submission process such as:

- Have any of the colleagues from authors respective institution read, reviewed or published in that specific scientific journal?

- Where is the journal indexed? Can it be found via databases which stands as usual tool to access, use or find specific scientific information?

- Is it associated with a scholarly society familiar to the author?

- Are there any reliable metrics associated with the journal (traditional or alternative)?

- Who is the editor? Who is on the editorial board? Are the members of the editorial board familiar to the author itself? Is there any available information about them?

- Does the scientific journal come with the regular trappings of a serial publication (e.g. ISSN's, DOI's, etc)? (http://blogs.scientificamerican.com/information-culture/2013/05/24/its-not-about-predators-its-about-journal-quality/).

The author has to make a distiction between so called "reputable journals" and "high-quality journals" (Jalalian, Mahboobi, 2014) bearing in mind that scientific work which he/she tends to publish can be endangered by applying the research to some questionable journals. Due to the fast acting of cyber criminals regarding the hijacking of the scientific journals, the authors are advised to act with extreme caution when submitting their research. They are also advised to be "up to date" with new information regarding this controversial topic by informing themselves through various websites and specialized scientific portals. It is highly recommended that the Beall's list of predatory publishers and journals should be consulted every time when an author plans to submit scientific work to some of the journals that are indexed by Thomson Re-
uters/Institute for Scientific Information-ISI and covered by the Journal Citation Report. Also, academic society in the Republic of Serbia needs to be more informed about this important issue by the competent institutions and working groups within the Ministry of Education, Science and Technological Development in order to prevent possible frauds. All this efforts in fighting and suppressing this new form of cyber crime within academic community can be strongly supported by a well organized open academic discussions on various levels. Providing an open lecture series with media support can be a useful tool in this matter. The question regarding predatory open access publishing represents an important issue that has to be briskly discussed within academic scientific community on national, regional and global level as well.

\section{References}

Basken, P. 2009. Open-Access Publisher Appears to Have Accepted Fake Paper From Bogus Center. The Chronicle of Higher Education. Retrieved from: http://chronicle.com/article/Open-Access-Publisher-Appears/47717

Beall, J. 2012. Predatory publishers are corrupting open access. Nature 489, 179.

Butler, D. 2013. Sham journals scam authors. Nature 495, 421-422.

Bohannon, J. 2013. Who's afraid of peer review? Science $342,60-65$

Garfield, E. 2006. The history and meaning of the journal impact factor. JAMA: the journal of the American Medical Association 295-1, 90-93. DOI:10.1001/ jama.295.1.90

Gilbert, N. 2009. Editor will quit over hoax paper. $\mathrm{Na}$ ture News. DOI:10.1038/news.2009.571

Jalalian, M., Mahboobi, H. 2014. Hijacked Journals and Predatory Publishers: Is There a Need to ReThink How to Assess the Quality of Academic Research? Walailak Journal of Science and Technology 11-5, 389-394.

Jalalian, M., Mahboobi, H. 2013. New corruption detected: Bogus impact factors compiled by fake organizations. Electronic Physician 5-3, 685-686.

Kolata, G. 2013. For Scientists, an Exploding World of Pseudo-Academia. The New York Times. Retrieved from http://www.nytimes.com/2013/04/o8/health/ for-scientists-an-exploding-world-of-pseudo-academia.html

Larsen, P. O., von Ins, M. 2010. The rate of growth in scientific publication and the decline in coverage provided by Science Citation Index. Scientometrics 84-3, 575-603. DOI:10.1007/s11192-010-0202-Z

Rahman, J., Dexters, N., Engels, T. C. E. 2014. Predatory open access journals in a performance-based 
funding model: Common journals in Beall's list and in the VABB-SHW. Report of the Gezaghebbende Panel. Expertisecentrum Onderzoek en Ontwikkelingsmonitoring - Centre for R\&D Monitoring, Antwerpen, 1-23pp.

$$
\approx
$$

http://scholarlyoa.com/2014/05/o2/red-alert-polishscholarly-journal-is-hijacked/

http://sylwan.ibles.waw.pl/pls/apex/

$$
\mathrm{f} ? \mathrm{p}=\text { SYLWAN:profil:o::.::// }
$$

http://www.scilogs.com/balkan_science_beat/serbian-journal-archives-of-biological-sciences-underinvestigation-following-accusation-of-predatorypractice/

http://scholarlyoa.com/individual-journals/ Retrieved on 26.07.2014.

http://scholarlyoa.com/publishers/ Retrieved on 26.07.2014. http://scholarlyoa.com/appeals Retrieved on 26.07.2014.

http://scholarlyoa.com/2012/11/3o/criteria-for-determining-predatory-open-access-publishers-2ndedition/ Retrived: 26.07 .2014$.

http://scholarlyoa.com/2014/o1/24/university-of-pristina-rector-under-fire-for-publishing-in-predatory-journals/

http: //www.journals. elsevier.com/the-journal-of-academic-librarianship/

http://www.sagepub.com/journals/Journal201675/title http://www.mehrdadjalalian.com/

http://www.unige.ch/sphn/

http://sylwan.ibles.waw.pl/pls/apex/f?p=105:1:0

http://sylwan.ibles.org/

http://kobson.nb.rs/kobson.82.html

http://blogs.scientificamerican.com/information-culture/2013/05/24/its-not-about-predators-its-aboutjournal-quality/

\section{Appendix}

\begin{tabular}{|c|c|c|c|}
\hline Academic Exchange Quarterly & $\begin{array}{l}\text { Interdisciplinary Journal of } \\
\text { Research in Business (IDJRB) }\end{array}$ & $\begin{array}{l}\text { International Journal of } \\
\text { Engineering, Science and } \\
\text { Technology }\end{array}$ & $\begin{array}{l}\text { International Journal of } \\
\text { Scientific Research in } \\
\text { Education }\end{array}$ \\
\hline $\begin{array}{l}\text { Academy of Contemporary } \\
\text { Research Journal (AOCRJ) }\end{array}$ & $\begin{array}{l}\text { International Ayurvedic } \\
\text { Medical Journal (IAMJ) }\end{array}$ & $\begin{array}{l}\text { International Journal of } \\
\text { Engineering Sciences \& } \\
\text { Research Technology (IJESRT) }\end{array}$ & $\begin{array}{l}\text { The International Journal of } \\
\text { Social Sciences (TIJOSS) }\end{array}$ \\
\hline $\begin{array}{l}\text { Acta de Gerencia Ciencia } \\
\text { (CAGENA) }\end{array}$ & $\begin{array}{l}\text { The International Asian } \\
\text { Research Journal (TIARJ) }\end{array}$ & $\begin{array}{l}\text { International Journal of } \\
\text { English and Education }\end{array}$ & $\begin{array}{l}\text { International Journal } \\
\text { of Social Sciences and } \\
\text { Entrepreneurship (IJSSE) }\end{array}$ \\
\hline $\begin{array}{l}\text { Acta Advances in Agricultural } \\
\text { Sciences (AAAS) }\end{array}$ & International Design Journal & $\begin{array}{l}\text { International Journal } \\
\text { of English Language \& } \\
\text { Translation Studies (IJ-ELTS) }\end{array}$ & $\begin{array}{l}\text { International Journal of Soft } \\
\text { Computing and Engineering }\end{array}$ \\
\hline Advances in Forestry Letter & $\begin{array}{l}\text { The International } \\
\text { Interdisciplinary Journal of } \\
\text { Education (IIJE) }\end{array}$ & $\begin{array}{l}\text { International Journal of } \\
\text { English Language, Literature } \\
\text { \& Humanities (IJELLH) }\end{array}$ & $\begin{array}{l}\text { International Journal of Sport } \\
\text { Studies (IJSS) }\end{array}$ \\
\hline $\begin{array}{l}\text { Al Ameen Journal of Medical } \\
\text { Sciences (AJMS) }\end{array}$ & $\begin{array}{l}\text { International Journal } \\
\text { Advances in Social Science } \\
\text { and Humanities (IJASSH) }\end{array}$ & $\begin{array}{l}\text { International Journal of } \\
\text { Farming and Allied Sciences }\end{array}$ & $\begin{array}{l}\text { International Journal of } \\
\text { Technical Research and } \\
\text { Applications (IJTRA) }\end{array}$ \\
\hline $\begin{array}{l}\text { Aloy Journal of Soft } \\
\text { Computing and Applications } \\
\text { (AJSCA) }\end{array}$ & $\begin{array}{l}\text { International Journal for } \\
\text { Pharmaceutical Research } \\
\text { Scholars (IJPRS) }\end{array}$ & $\begin{array}{l}\text { International Journal of } \\
\text { Fundamental \& Applied } \\
\text { Sciences }\end{array}$ & $\begin{array}{l}\text { International Journal } \\
\text { of Trends in Economics } \\
\text { Management and Technology } \\
\text { (IJTEMT) }\end{array}$ \\
\hline $\begin{array}{l}\text { American International } \\
\text { Journal of Contemporary } \\
\text { Research (AIJCR) }\end{array}$ & $\begin{array}{l}\text { International Journal for } \\
\text { Research \& Development in } \\
\text { Technology (IJRDT) }\end{array}$ & $\begin{array}{l}\text { International Journal of } \\
\text { Governance }\end{array}$ & $\begin{array}{l}\text { International Journal of } \\
\text { Universal Pharmacy and Bio } \\
\text { Sciences (IJUPBS) }\end{array}$ \\
\hline $\begin{array}{l}\text { American International } \\
\text { Journal of Contemporary } \\
\text { Scientific Research }\end{array}$ & $\begin{array}{l}\text { International Journal for } \\
\text { Scientific Research \& } \\
\text { Development }\end{array}$ & $\begin{array}{l}\text { International Journal of } \\
\text { Health Research }\end{array}$ & $\begin{array}{l}\text { International Journal of World } \\
\text { Research }\end{array}$ \\
\hline $\begin{array}{l}\text { American Journal of } \\
\text { Advanced Agricultural } \\
\text { Research (AJAAR) }\end{array}$ & $\begin{array}{l}\text { International Journal of } \\
\text { Abdominal Research (IJAR) }\end{array}$ & $\begin{array}{l}\text { International Journal of } \\
\text { Health Sciences and Research }\end{array}$ & $\begin{array}{l}\text { Internation al Journal on } \\
\text { Recent and Innovation } \\
\text { Trends in Computing and } \\
\text { Communication (IJRITCC) }\end{array}$ \\
\hline
\end{tabular}

Table 1. Potential, possible, or probable predatory scholarly open-access journals 


\begin{tabular}{|c|c|c|c|}
\hline $\begin{array}{l}\text { American Journal of } \\
\text { Advanced Drug Delivery }\end{array}$ & $\begin{array}{l}\text { International Journal of } \\
\text { Advanced Engineering and } \\
\text { Nano Technology (IJAENT) }\end{array}$ & $\begin{array}{l}\text { International Journal of } \\
\text { Human Resource and } \\
\text { Procurement (IJHRP) }\end{array}$ & $\begin{array}{l}\text { International Refereed Journal } \\
\text { of Engineering and Science } \\
\text { (IRJES) }\end{array}$ \\
\hline $\begin{array}{l}\text { American Journal of Advances } \\
\text { in Medical Science (ARNACA) }\end{array}$ & $\begin{array}{l}\text { International Journal of } \\
\text { Advanced Engineering } \\
\text { Applications }\end{array}$ & $\begin{array}{l}\text { International Journal of } \\
\text { Humanities and Social } \\
\text { Science Invention (IJHSSI) }\end{array}$ & $\begin{array}{l}\text { International Research Journal } \\
\text { of Applied and Basic Sciences } \\
\text { (IRJABS) }\end{array}$ \\
\hline $\begin{array}{l}\text { American Journal of } \\
\text { Engineering Research }\end{array}$ & $\begin{array}{l}\text { International Journal of } \\
\text { Advanced Research }\end{array}$ & $\begin{array}{l}\text { The International Journal of } \\
\text { Humanities \& Social Studies }\end{array}$ & $\begin{array}{l}\text { International Research Journal } \\
\text { of Applied Finance }\end{array}$ \\
\hline $\begin{array}{l}\text { American Journal of } \\
\text { Pharmacy and Health } \\
\text { Research (AJPHR) }\end{array}$ & $\begin{array}{l}\text { International Journal } \\
\text { of Advanced Research } \\
\text { in Computer and } \\
\text { Communication Engineering } \\
\text { (IJARCCE) }\end{array}$ & $\begin{array}{l}\text { International Journal of } \\
\text { Humanities, Engineering and } \\
\text { Pharmaceutical Sciences }\end{array}$ & $\begin{array}{l}\text { International Research } \\
\text { Journal of Pharmaceutical and } \\
\text { Applied Sciences (IRJPAS) }\end{array}$ \\
\hline $\begin{array}{l}\text { American Journal of } \\
\text { PharmTech Research (AJPTR) }\end{array}$ & $\begin{array}{l}\text { International Journal of } \\
\text { Advanced Research in } \\
\text { Computer Science and } \\
\text { Electronics Engineering } \\
\text { (IJARCSEE) }\end{array}$ & $\begin{array}{l}\text { International Journal } \\
\text { of Information and } \\
\text { Communication Research }\end{array}$ & International Researchers \\
\hline $\begin{array}{l}\text { American Journal of } \\
\text { Phytomedicine and Clinical } \\
\text { Therapeutics }\end{array}$ & $\begin{array}{l}\text { International Journal of } \\
\text { Advanced Research in } \\
\text { Computer Science and } \\
\text { Software Engineering } \\
\text { (IJARCSSE) }\end{array}$ & $\begin{array}{l}\text { International Journal } \\
\text { of Information and } \\
\text { Communication Technology } \\
\text { Research }\end{array}$ & $\begin{array}{l}\text { International Review of Social } \\
\text { Sciences and Humanities }\end{array}$ \\
\hline $\begin{array}{l}\text { American Journal of Scientific } \\
\text { Research }\end{array}$ & $\begin{array}{l}\text { International Journal } \\
\text { of Advanced Research } \\
\text { in Computer Science \& } \\
\text { Technology (IJARCST) }\end{array}$ & $\begin{array}{l}\text { International Journal of } \\
\text { Information Sources and } \\
\text { Services: A Research Journal } \\
\text { in Library Science (IJSS) }\end{array}$ & $\begin{array}{l}\text { International Technical } \\
\text { Sciences Journal (ITSJ) }\end{array}$ \\
\hline $\begin{array}{l}\text { American Journal of Social } \\
\text { issues and Humanities }\end{array}$ & $\begin{array}{l}\text { International Journal of } \\
\text { Advanced Research in } \\
\text { Electrical, Electronics and } \\
\text { Instrumentation Engineering } \\
\text { (IJAREEIE) }\end{array}$ & $\begin{array}{l}\text { International Journal of } \\
\text { Information Technology \& } \\
\text { Business Management }\end{array}$ & $\begin{array}{l}\text { Journal der Pharmazie } \\
\text { Forschung (RAPSR) }\end{array}$ \\
\hline American Research Journal & $\begin{array}{l}\text { International Journal of } \\
\text { Advanced Technology and } \\
\text { Engineering Research (IJATER) }\end{array}$ & $\begin{array}{l}\text { International Journal of } \\
\text { Information Technology \& } \\
\text { Computer Science (IJITCS) }\end{array}$ & $\begin{array}{l}\text { Journal of Advances in } \\
\text { Internal Medicine }\end{array}$ \\
\hline $\begin{array}{l}\text { Anglisticum: International } \\
\text { Journal of Literature, } \\
\text { Linguistics \& Interdisciplinary } \\
\text { Studies }\end{array}$ & $\begin{array}{l}\text { International Journal of } \\
\text { Advanced Technology and } \\
\text { Science (IJATS) }\end{array}$ & $\begin{array}{l}\text { International Journal of } \\
\text { Innovation in Science and } \\
\text { Mathematics (ISISM) }\end{array}$ & $\begin{array}{l}\text { Journal of American } \\
\text { Physicians and Surgeons } \\
\text { (JPANDS) }\end{array}$ \\
\hline Archives Des Sciences Journal & $\begin{array}{l}\text { International Journal of } \\
\text { Advancements in Mechanical } \\
\text { and Aeronautical Engineering }\end{array}$ & $\begin{array}{l}\text { International Journal of } \\
\text { Innovative Ideas }\end{array}$ & $\begin{array}{l}\text { Journal of Animal and Plant } \\
\text { Sciences (Nairobi, Kenya) }\end{array}$ \\
\hline $\begin{array}{l}\text { Archives of Biological } \\
\text { Sciences }\end{array}$ & $\begin{array}{l}\text { International Journal of } \\
\text { Advancements in Research \& } \\
\text { Technology (IJOART) }\end{array}$ & $\begin{array}{l}\text { International Journal of } \\
\text { Innovative Research and } \\
\text { Development }\end{array}$ & Journal of Applied Pharmacy \\
\hline $\begin{array}{l}\text { ARNACA American Journal of } \\
\text { Advances in Medical Science }\end{array}$ & $\begin{array}{l}\text { International Journal of } \\
\text { Advances in Engineering \& } \\
\text { Technology (IJAET) } \\
\end{array}$ & $\begin{array}{l}\text { International Journal of } \\
\text { Innovative Research and } \\
\text { Studies }\end{array}$ & $\begin{array}{l}\text { Journal of Applied } \\
\text { Pharmaceutical Science }\end{array}$ \\
\hline $\begin{array}{l}\text { Asia-Pacific Journal of } \\
\text { Research }\end{array}$ & $\begin{array}{l}\text { International Journal of } \\
\text { Advances in Management and } \\
\text { Economics (IJAME) }\end{array}$ & $\begin{array}{l}\text { International Journal of } \\
\text { Innovative Science and } \\
\text { Modern Engineering (IJISME) }\end{array}$ & $\begin{array}{l}\text { Journal of Ayurveda and } \\
\text { Holistic Medicine (JAHM) }\end{array}$ \\
\hline $\begin{array}{l}\text { Asian Journal of Biomedical } \\
\text { and Pharmaceutical Sciences }\end{array}$ & $\begin{array}{l}\text { International Journal of } \\
\text { Advances in Power Systems } \\
\text { (IJAPS) }\end{array}$ & $\begin{array}{l}\text { International Journal of } \\
\text { Innovative Technology and } \\
\text { Exploring Engineering (IJITEE) }\end{array}$ & $\begin{array}{l}\text { Journal of Basic and Clinical } \\
\text { Pharmacy [Link dead as of } \\
\text { 2013-05-06] }\end{array}$ \\
\hline $\begin{array}{l}\text { Asian Journal of Health and } \\
\text { Medical Sciences }\end{array}$ & $\begin{array}{l}\text { International Journal of } \\
\text { Agriculture and Crop Sciences } \\
\text { (IJACS) }\end{array}$ & $\begin{array}{l}\text { International Journal of } \\
\text { Innovative Technology and } \\
\text { Research }\end{array}$ & $\begin{array}{l}\text { Journal of Behavioral Sciences } \\
\text { in Asia }\end{array}$ \\
\hline
\end{tabular}




\begin{tabular}{|c|c|c|c|}
\hline $\begin{array}{l}\text { Asian Journal of Humanities } \\
\text { and Social Sciences }\end{array}$ & $\begin{array}{l}\text { International Journal of } \\
\text { Agriculture Innovations and } \\
\text { Research (IJAIR) }\end{array}$ & $\begin{array}{l}\text { International Journal } \\
\text { of Interdisciplinary and } \\
\text { Multidisciplinary Studies } \\
\text { (IJIMS) }\end{array}$ & Journal of Bio Innovation \\
\hline $\begin{array}{l}\text { Asian Journal of Business } \\
\text { and Management Sciences } \\
\text { (AJBMS) }\end{array}$ & $\begin{array}{l}\text { International Journal of } \\
\text { Agricultural Management \& } \\
\text { Development }\end{array}$ & $\begin{array}{l}\text { International Journal of } \\
\text { Inventions in Pharmaceutical } \\
\text { Sciences (IJIPS) }\end{array}$ & $\begin{array}{l}\text { Journal of Biomedical and } \\
\text { Pharmaceutical Research }\end{array}$ \\
\hline $\begin{array}{l}\text { Asian Journal of } \\
\text { Pharmaceutical and Health } \\
\text { Sciences }\end{array}$ & $\begin{array}{l}\text { International Journal of } \\
\text { Agronomy \& Plant Production }\end{array}$ & $\begin{array}{l}\text { International Journal of } \\
\text { Inventive Engineering and } \\
\text { Sciences (IJIES) }\end{array}$ & $\begin{array}{l}\text { Journal of Business } \\
\text { Management and Applied } \\
\text { Economics }\end{array}$ \\
\hline $\begin{array}{l}\text { Asian Journal of Pharmacy } \\
\text { and Life Science }\end{array}$ & $\begin{array}{l}\text { International Journal of } \\
\text { Application or Innovation in } \\
\text { Engineering \& Management } \\
\text { (IJAIEM) }\end{array}$ & $\begin{array}{l}\text { The International Journal of } \\
\text { Knowledge, Innovation and } \\
\text { Entreprenurship }\end{array}$ & $\begin{array}{l}\text { Journal of Business Research } \\
\text { (iş̧letme Araştırmaları } \\
\text { Dergisi)0 }\end{array}$ \\
\hline $\begin{array}{l}\text { Asian Journal of } \\
\text { Pharmaceutical Research and } \\
\text { Health Care (AJPRHC) }\end{array}$ & $\begin{array}{l}\text { International Journal } \\
\text { of Applied Biology and } \\
\text { Pharmaceutical Technology } \\
\text { (IJABPT) }\end{array}$ & $\begin{array}{l}\text { International Journal of } \\
\text { Language Learning and } \\
\text { Applied Linguistics World }\end{array}$ & $\begin{array}{l}\text { Journal of Chemical and } \\
\text { Pharmaceutical Sciences }\end{array}$ \\
\hline $\begin{array}{l}\text { International Journal of } \\
\text { Applied Economic Studies }\end{array}$ & $\begin{array}{l}\text { International Journal of Latest } \\
\text { Research in Engineering and } \\
\text { Computing (IJLREC) }\end{array}$ & Journal of Computing & $\begin{array}{l}\text { Australasian Journal of } \\
\text { Herpetology }\end{array}$ \\
\hline $\begin{array}{l}\text { International Journal of } \\
\text { Applied Linguistics \& English } \\
\text { Literature }\end{array}$ & $\begin{array}{l}\text { International Journal of Latest } \\
\text { Trends in Engineering, Science } \\
\text { and Technology (IJLTEST) }\end{array}$ & $\begin{array}{l}\text { Journal of Contemporary } \\
\text { Issues in Business Research }\end{array}$ & $\begin{array}{l}\text { International Journal of } \\
\text { Applied Research \& Studies } \\
\text { (iJARS) }\end{array}$ \\
\hline $\begin{array}{l}\text { International Journal of Law } \\
\text { and Legal Jurisprudence } \\
\text { Studies (IJlIJS) }\end{array}$ & $\begin{array}{l}\text { Journal of Coastal Life } \\
\text { Medicine }\end{array}$ & $\begin{array}{l}\text { Australian Journal of Basic } \\
\text { and Applied Sciences }\end{array}$ & $\begin{array}{l}\text { International Journal of } \\
\text { Applied Research \& Studies } \\
\text { (iJARS) }\end{array}$ \\
\hline $\begin{array}{l}\text { International Journal of Life } \\
\text { science and Pharma Research }\end{array}$ & Journal of Cosmology & $\begin{array}{l}\text { Australian Journal of Business } \\
\text { and Management Research } \\
\text { (AJBMR) }\end{array}$ & $\begin{array}{l}\text { International Journal of } \\
\text { Applied Sciences and } \\
\text { Biotechnology (IJASBT) }\end{array}$ \\
\hline $\begin{array}{l}\text { International Journal of Life } \\
\text { Sciences Biotechnology and } \\
\text { Pharma Research (IJLBPR) }\end{array}$ & $\begin{array}{l}\text { Journal of Current Pharma } \\
\text { Research }\end{array}$ & $\begin{array}{l}\text { Ayupharm: International } \\
\text { Journal of Ayurveda and } \\
\text { Allied Sciences }\end{array}$ & $\begin{array}{l}\text { International Journal of } \\
\text { Artificial Intelligence and } \\
\text { Mechatronics }\end{array}$ \\
\hline $\begin{array}{l}\text { The International Journal of } \\
\text { Management }\end{array}$ & $\begin{array}{l}\text { Journal of Current Trends in } \\
\text { Big Data Analytics }\end{array}$ & Bioinformation & $\begin{array}{l}\text { International Journal of Arts } \\
\text { and Entrepreneurship (IJAE) }\end{array}$ \\
\hline $\begin{array}{l}\text { International Journal of } \\
\text { Management and Business } \\
\text { Studies (IJMBS) }\end{array}$ & $\begin{array}{l}\text { Journal of ELT and Applied } \\
\text { Linguistics (JELTAL) }\end{array}$ & The Bioscan & $\begin{array}{l}\text { International Journal of } \\
\text { Ayurveda and Pharma } \\
\text { Research }\end{array}$ \\
\hline $\begin{array}{l}\text { International Journal of } \\
\text { Management, Economics and } \\
\text { Social Sciences (IJMESS) }\end{array}$ & $\begin{array}{l}\text { Journal of Electrical } \\
\text { Engineering }\end{array}$ & Bioresearch Bulletin & $\begin{array}{l}\text { International Journal of } \\
\text { Basic Medical Sciences and } \\
\text { Pharmacy (IJBMSP) }\end{array}$ \\
\hline $\begin{array}{l}\text { International Journal of } \\
\text { Management Research and } \\
\text { Business Strategy (IJMRBS) }\end{array}$ & $\begin{array}{l}\text { Journal of Emerging Trends in } \\
\text { Computing and Information } \\
\text { Sciences }\end{array}$ & Bioscience Discovery & $\begin{array}{l}\text { International Journal of Bio } \\
(\mathrm{IJOBIO})\end{array}$ \\
\hline $\begin{array}{l}\text { International Journal of } \\
\text { Management Sciences and } \\
\text { Business Research (IJMSBR) }\end{array}$ & $\begin{array}{l}\text { Journal of Environmental } \\
\text { Hydrology }\end{array}$ & $\begin{array}{l}\text { Biosciences, Biotechnology } \\
\text { Research Asia (BBRA) }\end{array}$ & $\begin{array}{l}\text { International Journal of } \\
\text { Biomedical Science }\end{array}$ \\
\hline $\begin{array}{l}\text { International Journal of } \\
\text { Mathematical Research \& } \\
\text { Science }\end{array}$ & $\begin{array}{l}\text { Journal of Experimental } \\
\text { Sciences }\end{array}$ & British Biomedical Bulletin & $\begin{array}{l}\text { International Journal of } \\
\text { Biosciences and Nanosciences } \\
\text { (IJBSANS) }\end{array}$ \\
\hline $\begin{array}{l}\text { International Journal of } \\
\text { Mathematics and Soft } \\
\text { Computing (IJMSC) }\end{array}$ & $\begin{array}{l}\text { Journal of Global Research in } \\
\text { Computer Science (JGRCS) }\end{array}$ & $\begin{array}{l}\text { British Journal of Economics, } \\
\text { Finance and Management } \\
\text { Sciences }\end{array}$ & $\begin{array}{l}\text { International Journal of } \\
\text { Business and Commerce }\end{array}$ \\
\hline $\begin{array}{l}\text { International Journal } \\
\text { of Medical Science and } \\
\text { Education (IJMSE) }\end{array}$ & $\begin{array}{l}\text { Journal of International } \\
\text { Academic Research for } \\
\text { Multidisciplinary (JIARM) }\end{array}$ & British Journal of Science & $\begin{array}{l}\text { The International Journal of } \\
\text { Business \& Management }\end{array}$ \\
\hline
\end{tabular}




\begin{tabular}{|c|c|c|c|}
\hline $\begin{array}{l}\text { International Journal of } \\
\text { Medical Sciences and Health } \\
\text { Care (IJMSHC) }\end{array}$ & $\begin{array}{l}\text { Journal of International } \\
\text { Environmental Application \& } \\
\text { Science }\end{array}$ & $\begin{array}{l}\text { Bulletin of Mathematical } \\
\text { Sciences \& Applications }\end{array}$ & $\begin{array}{l}\text { International Journal of } \\
\text { Bussiness and Management } \\
\text { Invention }\end{array}$ \\
\hline $\begin{array}{l}\text { International Journal of } \\
\text { Medical Research \& Health } \\
\text { Sciences (IJMRHS) }\end{array}$ & $\begin{array}{l}\text { Journal of International } \\
\text { Management Studies }\end{array}$ & $\begin{array}{l}\text { Bulletin of Pharmaceutical } \\
\text { Research }\end{array}$ & $\begin{array}{l}\text { International Journal of } \\
\text { Business and Social Research }\end{array}$ \\
\hline $\begin{array}{l}\text { International Journal of } \\
\text { Medicine and Biomedical } \\
\text { Research }\end{array}$ & $\begin{array}{l}\text { Journal of Knowledge } \\
\text { Management, Economics and } \\
\text { Information Technology }\end{array}$ & $\begin{array}{l}\text { Bulletin of Society for } \\
\text { Mathematical Services and } \\
\text { Standards }\end{array}$ & $\begin{array}{l}\text { International Journal of } \\
\text { Chemical and Pharmaceutical } \\
\text { Sciences (IJCPS) }\end{array}$ \\
\hline $\begin{array}{l}\text { International Journal of } \\
\text { Medicine and Biosciences }\end{array}$ & $\begin{array}{l}\text { Journal of Medical Research } \\
\text { and Practice (JMRP) }\end{array}$ & Calodema & $\begin{array}{l}\text { International Journal of } \\
\text { Communication Networks } \\
\text { and Information Security } \\
\text { (IJCNIS) }\end{array}$ \\
\hline $\begin{array}{l}\text { International Journal of } \\
\text { Medicobiologial Research }\end{array}$ & $\begin{array}{l}\text { Journal of Multidisciplinary } \\
\text { Engineering Science and } \\
\text { Technology (JMEST) }\end{array}$ & $\begin{array}{l}\text { Canadian Chemical } \\
\text { Transactions }\end{array}$ & $\begin{array}{l}\text { International Journal of } \\
\text { Computational Engineering } \\
\text { Research }\end{array}$ \\
\hline $\begin{array}{l}\text { International Journal of } \\
\text { Modern Engineering Research } \\
\text { (IJMER) }\end{array}$ & $\begin{array}{l}\text { Journal of Pharmaceutical and } \\
\text { Biomedical Sciences (JPBMS) }\end{array}$ & $\begin{array}{l}\text { Canadian Journal of Pure and } \\
\text { Applied Sciences }\end{array}$ & $\begin{array}{l}\text { International Journal of } \\
\text { Computer \& Electronics } \\
\text { Research (IJCER) }\end{array}$ \\
\hline $\begin{array}{l}\text { International Journal of } \\
\text { Multidisciplinary and Current } \\
\text { Research (IJMCR) }\end{array}$ & Journal of Science & Case Studies Journals & $\begin{array}{l}\text { International Journal of } \\
\text { Computer and Information } \\
\text { Technology (IJCIT) }\end{array}$ \\
\hline $\begin{array}{l}\text { International Journal of } \\
\text { Multidisciplinary Health } \\
\text { Sciences }\end{array}$ & Journal of Science Editing & $\begin{array}{l}\text { Chemical Science } \\
\text { Transactions }\end{array}$ & $\begin{array}{l}\text { International Journal of } \\
\text { Computer Applications }\end{array}$ \\
\hline $\begin{array}{l}\text { International Journal of } \\
\text { Multidisciplinary Sciences and } \\
\text { Engineering (IJMSE) }\end{array}$ & $\begin{array}{l}\text { Journal of Scientific Theory } \\
\text { and Methods }\end{array}$ & Computer Science Chronicle & $\begin{array}{l}\text { International Journal of } \\
\text { Computer Application and } \\
\text { Engineering Technology } \\
\text { (IJCAET) }\end{array}$ \\
\hline $\begin{array}{l}\text { International Journal of Novel } \\
\text { Drug Delivery Technology }\end{array}$ & $\begin{array}{l}\text { International Journal of } \\
\text { Sustainable Development SEE } \\
\text { OIDA International Journal of } \\
\text { Sustainable Development }\end{array}$ & Computer Science Journal & $\begin{array}{l}\text { International Journal of } \\
\text { Computer Applications in } \\
\text { Engineering Sciences (IJCAES) }\end{array}$ \\
\hline $\begin{array}{l}\text { International Journal of } \\
\text { Nursing }\end{array}$ & $\begin{array}{l}\text { Journal of } \\
\text { Telecommunications }\end{array}$ & $\begin{array}{l}\text { The Criterion: An } \\
\text { International Journal in } \\
\text { English }\end{array}$ & $\begin{array}{l}\text { International Journal of } \\
\text { Computer Science and } \\
\text { Business Informatics }\end{array}$ \\
\hline $\begin{array}{l}\text { International Journal of } \\
\text { Pharma and Bio Sciences } \\
\text { (IJPBS) }\end{array}$ & Kashmir Economic Review & Current Biotica & $\begin{array}{l}\text { International Journal of } \\
\text { Computer Science and } \\
\text { Information Security }\end{array}$ \\
\hline $\begin{array}{l}\text { International Journal of } \\
\text { Pharmaceutical \& Research } \\
\text { Science (IJPRS Journal) }\end{array}$ & $\begin{array}{l}\text { Lingua: International Journal } \\
\text { of Linguistics, Literature and } \\
\text { Culture (Lingua- IJLLC) }\end{array}$ & Current Discovery & $\begin{array}{l}\text { International Journal of } \\
\text { Computer Science and } \\
\text { Information Technologies }\end{array}$ \\
\hline $\begin{array}{l}\text { International Journal } \\
\text { of Pharmaceutical and } \\
\text { Biomedical Research }\end{array}$ & The Macrotheme Review & $\begin{array}{l}\text { Current Trends in Technology } \\
\text { and Sciences (CTTS) }\end{array}$ & $\begin{array}{l}\text { International Journal of } \\
\text { Computer Science and } \\
\text { Network (IJCSN) }\end{array}$ \\
\hline $\begin{array}{l}\text { International Journal } \\
\text { of Pharmaceutical and } \\
\text { Phytopharmacological } \\
\text { Research (elJPPR) }\end{array}$ & $\begin{array}{l}\text { Mathematical and } \\
\text { Computational Applications } \\
\text { (MCA) }\end{array}$ & The Dawn Journal & $\begin{array}{l}\text { International Journal of } \\
\text { Computer Science and } \\
\text { Network Security (IJCSNS) }\end{array}$ \\
\hline $\begin{array}{l}\text { International Journal of } \\
\text { Pharmaceutical Research and } \\
\text { Development (IJPRD) }\end{array}$ & Modern Behavioral Science & Direct Research Journals & $\begin{array}{l}\text { International Journal } \\
\text { of Computer Science } \\
\text { Engineering (IJCSE) }\end{array}$ \\
\hline $\begin{array}{l}\text { International Journal of } \\
\text { Pharmaceutical Science } \\
\text { Invention (IJPSI) }\end{array}$ & $\begin{array}{l}\text { The Modern Journal of } \\
\text { Applied Linguistics (MJAL) }\end{array}$ & $\begin{array}{l}\text { E-Library Science Research } \\
\text { Journal }\end{array}$ & $\begin{array}{l}\text { International Journal of } \\
\text { Computer Science Issues }\end{array}$ \\
\hline $\begin{array}{l}\text { National Journal of Basic } \\
\text { Medical Sciences }\end{array}$ & $\begin{array}{l}\text { ExcelingTech Publishing } \\
\text { Company, Ltd. }\end{array}$ & $\begin{array}{l}\text { International Journal of } \\
\text { Current Innovation Research } \\
\text { (IJCIR) }\end{array}$ & $\begin{array}{l}\text { International Journal of } \\
\text { Pharmaceutical Sciences and } \\
\text { Drug Research }\end{array}$ \\
\hline
\end{tabular}




\begin{tabular}{|c|c|c|c|}
\hline $\begin{array}{l}\text { National Journal of Medical } \\
\text { and Dental Research }\end{array}$ & $\begin{array}{l}\text { Elixir International Journal } \\
\text { (formerly Elixir Online } \\
\text { Journal) }\end{array}$ & $\begin{array}{l}\text { International Journal of } \\
\text { Current Microbiology and } \\
\text { Applied Sciences }\end{array}$ & $\begin{array}{l}\text { OIDA International Journal of } \\
\text { Sustainable Development }\end{array}$ \\
\hline $\begin{array}{l}\text { Euro-Afro Journal of Arts and } \\
\text { Social Sciences (EAJASS) }\end{array}$ & $\begin{array}{l}\text { International Journal of } \\
\text { Current Research }\end{array}$ & $\begin{array}{l}\text { International Journal of } \\
\text { Pharmaceutical Sciences and } \\
\text { Research (IJPSR) }\end{array}$ & $\begin{array}{l}\text { Open Access Journal of } \\
\text { Science and Technology }\end{array}$ \\
\hline European Academic Research & $\begin{array}{l}\text { International Journal of } \\
\text { Current Research and } \\
\text { Academic Review (IJCRAR) }\end{array}$ & $\begin{array}{l}\text { International Journal of } \\
\text { Pharmacognosy (IJP) }\end{array}$ & $\begin{array}{l}\text { Oriental Journal of Computer } \\
\text { Science and Technology }\end{array}$ \\
\hline $\begin{array}{l}\text { European Environmental } \\
\text { Sciences and Ecology Journal }\end{array}$ & $\begin{array}{l}\text { International Journal of } \\
\text { Current Research and Review }\end{array}$ & $\begin{array}{l}\text { International Journal of } \\
\text { Pharmacy }\end{array}$ & Pattern Recognition in Physics \\
\hline $\begin{array}{l}\text { European International } \\
\text { Journal of Applied Science } \\
\text { and Technology (Centre for } \\
\text { Promoting Knowledge [CPK], } \\
\text { UK) }\end{array}$ & $\begin{array}{l}\text { International Journal of } \\
\text { Current Science }\end{array}$ & $\begin{array}{l}\text { International Journal of } \\
\text { Pharmacy and Technology } \\
\text { (IJPT) }\end{array}$ & $\begin{array}{l}\text { People's Journal of Scientific } \\
\text { Research }\end{array}$ \\
\hline $\begin{array}{l}\text { European Journal of Academic } \\
\text { Essays (EJAE) }\end{array}$ & $\begin{array}{l}\text { International Journal of } \\
\text { Dental and Health Sciences }\end{array}$ & $\begin{array}{l}\text { International Journal of Plant, } \\
\text { Animal and Environmental } \\
\text { Sciences }\end{array}$ & $\begin{array}{l}\text { The Pharma Research } \\
\text { (Journal) }\end{array}$ \\
\hline $\begin{array}{l}\text { European Journal of Advanced } \\
\text { Computer Science (EJACS) }\end{array}$ & $\begin{array}{l}\text { International Journal of } \\
\text { Development Research }\end{array}$ & $\begin{array}{l}\text { International Journal of Power } \\
\text { Electronics Engineering }\end{array}$ & Pharmacologia \\
\hline $\begin{array}{l}\text { European Journal of } \\
\text { Biotechnology and Bioscience }\end{array}$ & $\begin{array}{l}\text { International Journal of } \\
\text { Digital Library Services } \\
\text { (IJODLS) }\end{array}$ & $\begin{array}{l}\text { International Journal of } \\
\text { Recent Scientific Research }\end{array}$ & PharmacologyOnline (PhOL) \\
\hline $\begin{array}{l}\text { European Journal of Business } \\
\text { and Social Sciences (EJBSS) }\end{array}$ & $\begin{array}{l}\text { International Journal of Drug } \\
\text { Development and Research } \\
\text { (IJDDR) }\end{array}$ & $\begin{array}{l}\text { International Journal of } \\
\text { Recent Technology and } \\
\text { Engineering (IJRTE) }\end{array}$ & $\begin{array}{l}\text { PHARMANEST: An } \\
\text { International Journal of } \\
\text { Advances in Pharmaceutical } \\
\text { Sciences }\end{array}$ \\
\hline $\begin{array}{l}\text { European Journal of } \\
\text { Contemporary Economics and } \\
\text { Management (EJCEM, EJEM) }\end{array}$ & $\begin{array}{l}\text { International Journal } \\
\text { of E-Computer Science } \\
\text { Evolution }\end{array}$ & $\begin{array}{l}\text { International Journal of } \\
\text { Recent Trends in Electrical } \\
\text { \& Electronics Engineering } \\
\text { (IJRTE) }\end{array}$ & Plant Digest \\
\hline $\begin{array}{l}\text { European Journal of } \\
\text { Educational Research (EUJER) }\end{array}$ & $\begin{array}{l}\text { International Journal of } \\
\text { Economics and Finance (IJEF) }\end{array}$ & $\begin{array}{l}\text { International Journal of } \\
\text { Research and Innovation } \\
\text { in Computer Engineering } \\
\text { (IJRICE) }\end{array}$ & $\begin{array}{l}\text { Pure and Applied Biology } \\
\text { (PAB) }\end{array}$ \\
\hline $\begin{array}{l}\text { European Journal of } \\
\text { Educational Sciences (EJES) }\end{array}$ & $\begin{array}{l}\text { International Journal of } \\
\text { Economics and Research }\end{array}$ & $\begin{array}{l}\text { International Journal of } \\
\text { Research Development } \\
\text { (IJORD) }\end{array}$ & $\begin{array}{l}\text { Reef Resources Assessment } \\
\text { and Management Technical } \\
\text { Paper }\end{array}$ \\
\hline $\begin{array}{l}\text { European Journal of Natural } \\
\text { History (EJNH) }\end{array}$ & $\begin{array}{l}\text { International Journal of } \\
\text { Economics, Commerce and } \\
\text { Management (IJECM) }\end{array}$ & $\begin{array}{l}\text { International Journal of } \\
\text { Research in Aeronautical } \\
\text { and Mechanical Engineering } \\
\text { (IJRAME) }\end{array}$ & Research \\
\hline $\begin{array}{l}\text { European Journal of Scientific } \\
\text { Research }\end{array}$ & $\begin{array}{l}\text { The International Journal of } \\
\text { Educational and Psychological } \\
\text { Assessment }\end{array}$ & $\begin{array}{l}\text { International Journal of } \\
\text { Research in Agricultural } \\
\text { Sciences (IJRAS) }\end{array}$ & $\begin{array}{l}\text { Research Directions: } \\
\text { International Multidisciplinary } \\
\text { Research Journal (Research } \\
\text { Directions Journal }\end{array}$ \\
\hline $\begin{array}{l}\text { European Journal of } \\
\text { Sustainable Development }\end{array}$ & $\begin{array}{l}\text { International Journal of } \\
\text { Electrochemical Science }\end{array}$ & $\begin{array}{l}\text { International Journal of } \\
\text { Research in Ayurveda and } \\
\text { Pharmacy }\end{array}$ & Research in Biotechnology \\
\hline $\begin{array}{l}\text { European Law and Politics } \\
\text { Journal (ELPJ) }\end{array}$ & $\begin{array}{l}\text { International Journal of } \\
\text { Electronics and Computer } \\
\text { Research (IJECR) }\end{array}$ & $\begin{array}{l}\text { International Journal of } \\
\text { Research in Computer and } \\
\text { Communication Technology }\end{array}$ & $\begin{array}{l}\text { Research Inventy: } \\
\text { International Journal of } \\
\text { Engineering and Science }\end{array}$ \\
\hline European Scientific Journal & $\begin{array}{l}\text { International Journal of } \\
\text { Electronics Communication } \\
\text { and Computer Engineering }\end{array}$ & $\begin{array}{l}\text { International Journal of } \\
\text { Research in Computer Science }\end{array}$ & $\begin{array}{l}\text { Research Journal of } \\
\text { Pharmaceutical, Biological } \\
\text { and Chemical Sciences } \\
\text { (RJPBCS) }\end{array}$ \\
\hline
\end{tabular}




\begin{tabular}{|c|c|c|c|}
\hline $\begin{array}{l}\text { FLUIDS: International Journal } \\
\text { of Medical Fluid Management }\end{array}$ & $\begin{array}{l}\text { International Journal of } \\
\text { Electronics Communication } \\
\text { and Computer Technology } \\
\text { (IJECCT) }\end{array}$ & $\begin{array}{l}\text { International Journal of } \\
\text { Research in Computer } \\
\text { Technology }\end{array}$ & Research Revolution \\
\hline $\begin{array}{l}\text { FOREX Technical Journal } \\
\text { Library }\end{array}$ & $\begin{array}{l}\text { International Journal of } \\
\text { Emerging Science and } \\
\text { Engineering (IJESE) }\end{array}$ & $\begin{array}{l}\text { International Journal of } \\
\text { Research in Engineering } \\
\text { and Advanced Technology } \\
\text { (IJREAT) }\end{array}$ & ResearchDesk \\
\hline $\begin{array}{l}\text { Frontiers in Aerospace } \\
\text { Engineering }\end{array}$ & $\begin{array}{l}\text { International Journal of } \\
\text { Emerging Sciences (IJES) }\end{array}$ & $\begin{array}{l}\text { International Journal of } \\
\text { Research in Engineering and } \\
\text { Science }\end{array}$ & $\begin{array}{l}\text { Researchers World - Journal } \\
\text { of Arts Science \& Commerce }\end{array}$ \\
\hline $\begin{array}{l}\text { Galaxy: International } \\
\text { Multidisciplinary Research } \\
\text { Journal }\end{array}$ & $\begin{array}{l}\text { International Journal of } \\
\text { Emerging Technology and } \\
\text { Advanced Engineering }\end{array}$ & $\begin{array}{l}\text { International Journal of } \\
\text { Research in Engineering and } \\
\text { Technology (IJRET) }\end{array}$ & Review of Research \\
\hline $\begin{array}{l}\text { Global Journal of } \\
\text { Management Science and } \\
\text { Technology }\end{array}$ & $\begin{array}{l}\text { International Journal of } \\
\text { Energy \& Technology }\end{array}$ & $\begin{array}{l}\text { International Journal of } \\
\text { Research in Medical and } \\
\text { Dental Sciences }\end{array}$ & Reviews of Progress \\
\hline $\begin{array}{l}\text { Global Journal of Medical and } \\
\text { Health Sciences (GJM) }\end{array}$ & $\begin{array}{l}\text { International Journal of } \\
\text { Engineering and Advanced } \\
\text { Technology (IJEAT) }\end{array}$ & $\begin{array}{l}\text { International Journal of } \\
\text { Research in Wireless Systems } \\
\text { (IJRWS) }\end{array}$ & $\begin{array}{l}\text { Revista Iberoamericana de } \\
\text { Ciencas }\end{array}$ \\
\hline $\begin{array}{l}\text { Global Journal of Medicine } \\
\text { and Public Health }\end{array}$ & $\begin{array}{l}\text { International Journal of } \\
\text { Engineering and Applied } \\
\text { Sciences }\end{array}$ & $\begin{array}{l}\text { International Journal of } \\
\text { Reviews in Computing }\end{array}$ & $\begin{array}{l}\text { Romanian Biotechnological } \\
\text { Letters }\end{array}$ \\
\hline Golden Research Thoughts & $\begin{array}{l}\text { International Journal of } \\
\text { Engineering and Computer } \\
\text { Science (IJECS) }\end{array}$ & $\begin{array}{l}\text { International Journal of } \\
\text { Science and Advanced } \\
\text { Technology (IJSAT) }\end{array}$ & $\begin{array}{l}\text { Sci-Afric Journal of Scientific } \\
\text { Issues, Research and Essays }\end{array}$ \\
\hline $\begin{array}{l}\text { Hygeia: Journal for Drugs and } \\
\text { Medicines }\end{array}$ & $\begin{array}{l}\text { International Journal of } \\
\text { Engineering and Innovative } \\
\text { Technology (IJEIT) }\end{array}$ & $\begin{array}{l}\text { The International Journal of } \\
\text { Science \& Technoledge }\end{array}$ & Science International \\
\hline $\begin{array}{l}\text { Indian Journal of Applied- } \\
\text { Basic Medical Sciences }\end{array}$ & $\begin{array}{l}\text { International Journal of } \\
\text { Engineering and Management } \\
\text { Research (IJEMR) }\end{array}$ & $\begin{array}{l}\text { International Journal of } \\
\text { Science and Research }\end{array}$ & Science Park \\
\hline $\begin{array}{l}\text { Indian Journal of Applied } \\
\text { Research }\end{array}$ & $\begin{array}{l}\text { The IJES: The International } \\
\text { Journal of Engineering and } \\
\text { Science }\end{array}$ & $\begin{array}{l}\text { International Journal of } \\
\text { Science and Technology }\end{array}$ & Science Postprint (SPP) \\
\hline $\begin{array}{l}\text { Indian Journal of } \\
\text { Pharmaceutical and Biological } \\
\text { Research (IJPBR) }\end{array}$ & $\begin{array}{l}\text { International Journal of } \\
\text { Engineering and Science } \\
\text { Invention (IJESI) }\end{array}$ & $\begin{array}{l}\text { International Journal of } \\
\text { Science Commerce and } \\
\text { Humanities (IJSCH) }\end{array}$ & Science Research Reporter \\
\hline $\begin{array}{l}\text { Indian Journal of Research } \\
\text { Anvikshiki }\end{array}$ & $\begin{array}{l}\text { International Journal of } \\
\text { Engineering Innovations and } \\
\text { Research (IJEIR) }\end{array}$ & $\begin{array}{l}\text { International Journal of } \\
\text { Science Innovations and } \\
\text { Discoveries }\end{array}$ & Science Reuters \\
\hline $\begin{array}{l}\text { Indian Journal of Research in } \\
\text { Pharmacy and Biotechnology } \\
\text { (IJRPB) }\end{array}$ & $\begin{array}{l}\text { International Journal of } \\
\text { Engineering Inventions }\end{array}$ & $\begin{array}{l}\text { International Journal of } \\
\text { Sciences (IJSciences) }\end{array}$ & $\begin{array}{l}\text { Scientific Research Journal } \\
\text { (Scirj) }\end{array}$ \\
\hline $\begin{array}{l}\text { Indian Journal of Scientific } \\
\text { Research (IJSR) }\end{array}$ & $\begin{array}{l}\text { International Journal of } \\
\text { Engineering Research }\end{array}$ & $\begin{array}{l}\text { International Journal of } \\
\text { Scientific \& Technology } \\
\text { Research }\end{array}$ & Scientific World \\
\hline $\begin{array}{l}\text { Indian Streams Research } \\
\text { Journal }\end{array}$ & $\begin{array}{l}\text { International Journal of } \\
\text { Engineering Research and } \\
\text { Applications }\end{array}$ & $\begin{array}{l}\text { International Journal of } \\
\text { Scientific and Engineering } \\
\text { Research (IJSER) }\end{array}$ & $\begin{array}{l}\text { Seventh Sense Research } \\
\text { Group Journal }\end{array}$ \\
\hline $\begin{array}{l}\text { Indo American Journal of } \\
\text { Pharmaceutical Research }\end{array}$ & $\begin{array}{l}\text { International Journal of } \\
\text { Engineering Research and } \\
\text { Development (IJERD) }\end{array}$ & $\begin{array}{l}\text { International Journal of } \\
\text { Scientific and Research } \\
\text { Publications (IJSRP) }\end{array}$ & $\begin{array}{l}\text { South Asian Journal of } \\
\text { Mathematics }\end{array}$ \\
\hline $\begin{array}{l}\text { Indo-Global Journal of } \\
\text { Pharmaceutical Sciences }\end{array}$ & $\begin{array}{l}\text { International Journal of } \\
\text { Engineering Research and } \\
\text { Science \& Technology } \\
\text { (IJERST) }\end{array}$ & $\begin{array}{l}\text { International Journal of } \\
\text { Scientific Engineering and } \\
\text { Technology }\end{array}$ & $\begin{array}{l}\text { Swiss Journal of Research in } \\
\text { Business and Social Science } \\
\text { (SJRBSS) }\end{array}$ \\
\hline
\end{tabular}


Lukić Tin, Blešić Ivana, Basarin Biljana, Ivanović Bibić Ljubica, Milošević Dragan, Sakulski Dušan

\begin{tabular}{|c|c|c|c|}
\hline $\begin{array}{l}\text { Innovations in } \\
\text { Pharmaceuticals and } \\
\text { Pharmacotherapy (IPP) }\end{array}$ & $\begin{array}{l}\text { International Journal of } \\
\text { Engineering Science \& } \\
\text { Advanced Technology }\end{array}$ & $\begin{array}{l}\text { International Journal of } \\
\text { Scientific Research }\end{array}$ & $\begin{array}{l}\text { Tactful Management Research } \\
\text { Journal (TMRJ) }\end{array}$ \\
\hline $\begin{array}{l}\text { Interdisciplinary Journal of } \\
\text { Contemporary Research in } \\
\text { Business }\end{array}$ & $\begin{array}{l}\text { International Journal of } \\
\text { Engineering Science and } \\
\text { Innovative Technology } \\
\text { (IJESIT) }\end{array}$ & $\begin{array}{l}\text { International Journal of } \\
\text { Scientific Research and } \\
\text { Application (IJSRA Publishing) }\end{array}$ & $\begin{array}{l}\text { Technics Technologies } \\
\text { Education Management }\end{array}$ \\
\hline \multirow{5}{*}{\multicolumn{3}{|c|}{$\begin{array}{l}\text { This is a list of questionable, scholarly open-access journals. The recommendation is that } \\
\text { scholars read the available reviews, assessments and descriptions on similar topics, and then } \\
\text { decide for themselves whether they want to submit articles, serve as editors or on editorial } \\
\text { boards. }\end{array}$}} & $\begin{array}{l}\text { Universal Journal of Applied } \\
\text { Computer Science and } \\
\text { Technology }\end{array}$ \\
\hline & & & $\begin{array}{l}\text { Universal Journal of } \\
\text { Computer Science and } \\
\text { Engineering Technology } \\
\text { (UniCSE) }\end{array}$ \\
\hline & & & $\begin{array}{l}\text { Universal Journal of Pharmacy } \\
\text { (UJP Online) }\end{array}$ \\
\hline & & & $\begin{array}{l}\text { Weekly Science International } \\
\text { Research Journal }\end{array}$ \\
\hline & & & $\begin{array}{l}\text { World Applied Sciences } \\
\text { Journal }\end{array}$ \\
\hline \multirow{4}{*}{\multicolumn{3}{|c|}{$\begin{array}{l}\text { This list is kept up-to-date to the best extent possible but may not reflect sudden, unreported, } \\
\text { or unknown enhancements. }\end{array}$}} & World Essays Journal (WEJ) \\
\hline & & & $\begin{array}{l}\text { World Journal of } \\
\text { Pharmaceutical Research } \\
\text { (WJPR) }\end{array}$ \\
\hline & & & $\begin{array}{l}\text { World Journal of Pharmacy } \\
\text { and Pharmaceutical Sciences } \\
\text { (WJPPS) }\end{array}$ \\
\hline & & & $\begin{array}{l}\text { World Journal of Science and } \\
\text { Technology (WJST) }\end{array}$ \\
\hline
\end{tabular}

Source: http://scholarlyoa.com/individual-journals/ 